University of Nebraska - Lincoln

DigitalCommons@University of Nebraska - Lincoln

USDA Wildlife Services - Staff Publications

U.S. Department of Agriculture: Animal and Plant Health Inspection Service

2015

\title{
Establishing a definition of polar bear (Ursus maritimus) health: A guide to research and management activities
}

\author{
Kelly A. Park \\ Center for Epidemiology and Animal Health, Science Technology and Analysis Services, Veterinary \\ Services, Animal and Plant Health Inspection Service, U.S. Department of Agriculture \\ Colleen Duncan \\ Colorado State University \\ Pauline Noi \\ National Wildlife Research Center, Veterinary Services, Animal and Plant Health Inspection Service, U.S. \\ Department of Agriculture \\ Christian Sonne \\ Aarhus University, Denmark \\ Kristin Laidre \\ University of Washington
}

See next page for additional authors

Follow this and additional works at: https://digitalcommons.unl.edu/icwdm_usdanwrc

Part of the Life Sciences Commons

Park, Kelly A.; Duncan, Colleen; Noi, Pauline; Sonne, Christian; Laidre, Kristin; Obbard, Martyn; Wiig, Oystein; Aars, Jon; Regehr, Eric; Gustafson, Lori L.; and Atwood, Todd, "Establishing a definition of polar bear (Ursus maritimus) health: A guide to research and management activities" (2015). USDA Wildlife Services - Staff Publications. 1711.

https://digitalcommons.unl.edu/icwdm_usdanwrc/1711

This Article is brought to you for free and open access by the U.S. Department of Agriculture: Animal and Plant Health Inspection Service at DigitalCommons@University of Nebraska - Lincoln. It has been accepted for inclusion in USDA Wildlife Services - Staff Publications by an authorized administrator of DigitalCommons@University of Nebraska - Lincoln. 


\section{Authors}

Kelly A. Park, Colleen Duncan, Pauline Noi, Christian Sonne, Kristin Laidre, Martyn Obbard, Oystein Wiig, Jon Aars, Eric Regehr, Lori L. Gustafson, and Todd Atwood 


\title{
Establishing a definition of polar bear (Ursus maritimus) health: A guide to research and management activities
}

\author{
Kelly A. Patyk ${ }^{\mathrm{a}, *}$, Colleen Duncan ${ }^{\mathrm{b}}$, Pauline $\mathrm{Nol}^{\mathrm{c}}{ }^{\mathrm{C}}$, Christian Sonne ${ }^{\mathrm{d}}$, Kristin Laidre ${ }^{\mathrm{e}}$, Martyn Obbard ${ }^{\mathrm{f}}$, \\ Øystein Wiig ${ }^{\mathrm{g}}$, Jon Aars ${ }^{\mathrm{h}}$, Eric Regehr ${ }^{\mathrm{i}}$, Lori L. Gustafson ${ }^{\mathrm{a}}$, Todd Atwood ${ }^{\mathrm{j}}$
}

\footnotetext{
a Center for Epidemiology and Animal Health, Science Technology and Analysis Services, Veterinary Services, Animal and Plant Health Inspection Service, U.S. Department of Agriculture, USA

b Colorado State University Veterinary Diagnostic Laboratory, Colorado State University, USA

${ }^{c}$ National Wildlife Research Center, Veterinary Services, Animal and Plant Health Inspection Service, U.S. Department of Agriculture, USA

${ }^{\mathrm{d}}$ Aarhus University, Faculty of Science and Technology, Department of Bioscience, Arctic Research Centre (ARC), Denmark

e Polar Science Center, Applied Physics Laboratory, University of Washington, USA

${ }^{\mathrm{f}}$ Wildlife Research and Monitoring Section, Ontario Ministry of Natural Resources and Forestry, Canada

g Natural History Museum, University of Oslo, Norway

${ }^{\text {h }}$ Norwegian Polar Institute, Norway

${ }^{\mathrm{i}}$ U.S. Fish and Wildlife Service, Marine Mammals Management Program, USA

${ }^{j}$ U.S. Geological Survey, Alaska Science Center, USA
}

\section{H I G H L I G H T S}

- We use the Delphi method to define polar bear (Ursus maritimus) health.

- We identify challenges in measuring health and outline health metrics.

- Health is defined by characteristics and knowledge at multiple levels.

- Fifteen metrics were identified to monitor polar bear health.

- A cumulative effects approach could provide measureable conservation objectives.

\section{A R T I C L E I N F O}

\section{Article history:}

Received 12 December 2014

Received in revised form 2 February 2015

Accepted 3 February 2015

Available online 11 February 2015

Editor: D. Barcelo

\section{Keywords:}

Delphi

Polar bear

Survey

Ursus maritimus

Wildlife health

\section{GRAPHICALABSTRACT}

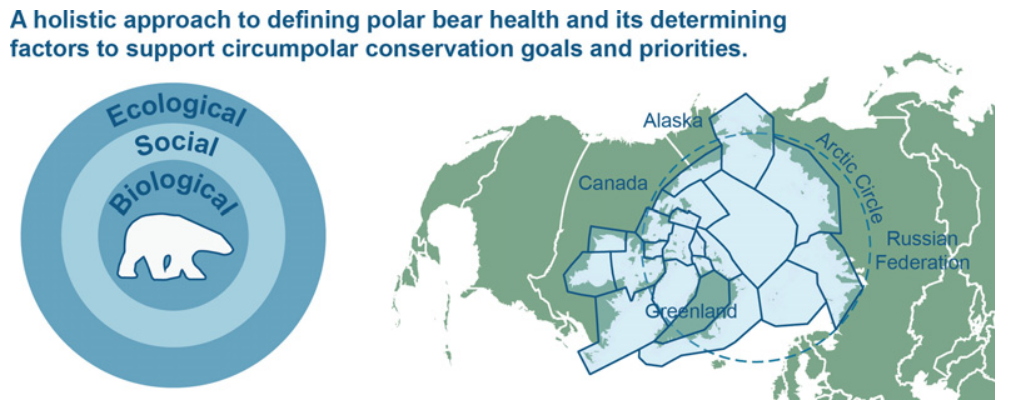

\begin{abstract}
A B S T R A C T
The meaning of health for wildlife and perspectives on how to assess and measure health, are not well characterized. For wildlife at risk, such as some polar bear (Ursus maritimus) subpopulations, establishing comprehensive monitoring programs that include health status is an emerging need. Environmental changes, especially loss of sea ice habitat, have raised concern about polar bear health. Effective and consistent monitoring of polar bear health requires an unambiguous definition of health. We used the Delphi method of soliciting and interpreting expert knowledge to propose a working definition of polar bear health and to identify current concerns regarding health, challenges in measuring health, and important metrics for monitoring health. The expert opinion elicited through the exercise agreed that polar bear health is defined by characteristics and knowledge at the individual, population, and ecosystem level. The most important threats identified were in decreasing order: climate change, increased nutritional stress, chronic physiological stress, harvest management, increased exposure to contaminants, increased frequency of human interaction, diseases and parasites, and increased exposure to competitors. Fifteen metrics were identified to monitor polar bear health. Of these, indicators of body condition, disease and parasite exposure, contaminant exposure, and reproductive success were ranked as most important. We suggest
\end{abstract}

\footnotetext{
* Corresponding author at: 2150 Centre Avenue, Building B, Fort Collins, CO 80526, USA.

E-mail addresses: Kelly.A.Patyk@aphis.usda.gov (K.A. Patyk), tatwood@usgs.gov (T. Atwood).
} 
that a cumulative effects approach to research and monitoring will improve the ability to assess the biological, ecological, and social determinants of polar bear health and provide measurable objectives for conservation goals and priorities and to evaluate progress.

Published by Elsevier B.V.

\section{Introduction}

The topic of health among wildlife populations has received increasing attention for informing management and policy decisions. However, "health" remains a difficult concept to define and assess (Deem et al., 2008; Gunnarsson, 2006; Hanisch et al., 2012; Nordenfelt, 2011; Stephen, 2014; Stephen and Karesh, 2014). In part, this is because health is not a static term and tends to be defined and framed in different ways depending on the specific approach and context in which it is addressed. For example, population ecologists often express health as a function of population vital rates (e.g., survival or recruitment) or by body condition, whereas wildlife veterinarians base it on physiological and epidemiological manifestations (e.g., rates of infection, incidence of disease). Both forms of expression are valid, but the greatest conservation utility may be achieved by developing a definition of health that is multidisciplinary in nature (Hanisch et al., 2012; Stephen, 2014). We suggest that a better understanding of the concept of population health is needed for species of concern, such as the polar bear (Ursus maritimus), given the potential risks from anthropogenically caused negative health effects.

Climate-mediated changes in the Arctic environment, such as reductions in sea ice distribution and duration, may have negative consequences for sea-ice obligate marine mammals including polar bears (Stirling and Derocher, 2012; Stirling and Parkinson, 2006). Fragmentation and decreased spatial and temporal availability of their sea ice habitat can have negative impacts on the accessibility of their primary prey, i.e., seals (Derocher, 2010; Durner et al., 2009; Wiig, 2005). For example, decreased hunting opportunities and availability of prey can lead to nutritional stress and reduced body size, and may affect reproductive success and survival (Molnár et al., 2011; Regehr et al., 2007; Rode et al., $2010,2014)$. In some species, energetic stress may lead to suppression of the immune system and thereby increased mortality and reduced reproductive rates (e.g., Boonstra et al., 2001; Wayland et al., 2002). Impairment of the innate and adaptive immune systems from oral exposure to organohalogen-polluted marine mammal blubber is possible because polar bears rely on this food source for thermoregulation and energy needs (AMAP, 1998, 2003, 2004; Letcher et al., 2010). In certain regions polar bears have increased their presence on land due to loss of sea ice habitat, with documented landward shifts of denning, increased duration of use of terrestrial habitat during summer and fall, and increased scavenging of human-provisioned resources (Bentzen et al., 2007; Fischbach et al., 2007; Herreman and Peacock, 2013; Lunn et al., 2002; Schliebe et al., 2008; Towns et al., 2010). In some areas, this has led to a rise in human-bear interactions (Aars et al., 2006; Lunn et al., 2002; Stirling and Parkinson, 2006; Towns et al., 2009), and human activity is projected to increase in many parts of the Arctic as shipping routes open due to loss of sea ice and resource extraction increases (Reeves et al., 2014). Aggregations of polar bears on land may also increase levels of interactions among the bears and with other wildlife species, which could potentially increase disease transmission of novel pathogens and additional stressors to polar bears.

Research on some of the 19 recognized polar bear subpopulations has been conducted for decades for conservation and management of subsistence harvests (Obbard et al., 2010). The breadth and topics covered by this research have varied; however, there has been modest focus on health and little is known about disease and health status in polar bears (Fagre et al., unpublished results; Hueffer et al., 2011, 2013; Letcher et al., 2010; Sonne, 2010; Sonne et al., 2012; Vongraven et al., 2012). Vongraven et al. (2012) outlined a circumpolar monitoring framework for polar bears and specifically noted the importance of monitoring population health. Additionally, marine mammals may be effective sentinels to monitor and assess ecosystem health (Aguirre and Tabor, 2004; Bossart, 2011). As an apex predator and a marine mammal sensitive to the effects of climate-induced habitat change (e.g., Hobson and Welch, 1992; Laidre et al., 2008; Regehr et al., 2010; Rode et al., 2010; Sonne et al., 2012), polar bears may act as a sentinel species to evaluate the potential health effects of environmental change on other wildlife species, humans, and the Arctic ecosystem (Moore, 2008; Moore and Huntington, 2008). A clear definition of polar bear health is critical, particularly in the current regulatory environment, to guide research, provide measureable objectives for establishing conservation goals and priorities, and provide well-defined indicators to measure progress towards those goals and priorities.

The Delphi method is an iterative process intended to systematically elicit and summarize the knowledge and opinions of a group of experts by using a series of questionnaires (Dalkey and Helmer, 1962; Rowe and Wright, 1999). The questionnaires are each structured to expand on, and confirm, the results of the previous. This provides opportunities for experts to clarify and revise responses, ensuring accurate representations of their judgments. The purpose of this study was to apply the Delphi method to advance the efforts of Vongraven et al. (2012) by establishing a definition of polar bear health which can be used in circumpolar monitoring plans. The overall objectives were, through systematic elicitation of expert knowledge, to (1) suggest a working definition of health as it applies to polar bears, (2) identify current concerns regarding polar bear health, and (3) outline important indicators to monitor health in polar bears.

\section{Materials and methods}

A two-round Delphi exercise was conducted electronically to explore the concept of polar bear health and to consider how it may influence research and management decisions. Participants $(n=15)$ were identified by their peers as having extensive experience and key insights related to the research and management of polar bears. Prospective participants were contacted via email with a description of the study objectives and an invitation to participate. Experts unable to participate were encouraged to suggest an alternative representative, if appropriate. Experts who accepted the invitation to participate in the study received a subsequent email describing the Delphi study process along with the first questionnaire.

\subsection{Study and questionnaire design}

Each questionnaire was pretested prior to distribution as an attachment to an instructional email sent to each participant individually (Supplemental material). Completed questionnaires were returned as email attachments to one of the researchers and responses were recorded anonymously under a respondent number. Three members of the research team, blind to the respondent names, worked independently to review the responses from the questionnaires. As a group, the three members then compared and discussed the responses to generate quantitative or qualitative results, as appropriate. Results of the first round were used to guide the construction of the questionnaire for the second-round exercise.

The first-round questionnaire consisted of four questions: three open-ended questions and one two-part question comprised of a closed-ended question with scalar responses (e.g., a scale of 1-10 
where 1 meant little to no agreement and 10 meant perfect agreement) and an open-ended follow-up question. Participants were also encouraged to provide additional comments if desired.

The second round of the Delphi exercise included aggregated results from the first-round questionnaire and a new set of questions. Secondround questions were closed-ended with scalar responses and one check-all-that-apply question. Participants were encouraged to provide comments regarding the aggregated results and to provide additional information or justification for their responses. Both rounds of the questionnaire focused on the four major topics in the subheadings below.

\subsection{Defining polar bear health}

The first-round questionnaire included the summary statement of a previous Delphi exercise involving wildlife health professionals to define "wildlife health" for the purposes of guiding wildlife health management (Hanisch et al., 2012). The summary statement from that study was: "Wildlife health is a multidisciplinary concept and is concerned with multiple stressors that affect wildlife. Wildlife health can be applied to individuals, populations, and ecosystems, but its most important defining characteristics are whether a population can respond appropriately to stresses and sustain itself." Participants were asked to indicate on a scale of 1 to 10 how well the definition by Hanisch et al. (2012) applies to polar bear health (anchored by $1=$ "little agreement with the definition of wildlife health, and not at all applicable to polar bear health" to $10=$ "the definition of wildlife health applies exactly to polar bear health without change"). If they responded with a score less than 10 , participants were asked in a follow-up question to specify what should be changed to improve the definition.

In the second round, participants received descriptive statistics summarizing the expert group's level of agreement with the wildlife health definition, and they were provided with a condensed list of 17 proposed changes to the definition. For each of the proposed changes, participants were asked to rate whether the change would "improve," "decrease," or "neither improve nor decrease" their level of agreement with the definition of polar bear health.

\subsection{Identifying the most significant concerns to polar bear health over the next 20 years}

Participants were asked in the first round to identify what they consider to be the most significant concerns to polar bear health over the next 20 years. Central themes and concepts which emerged from the first-round responses were summarized into a list of eight concerns. In the second round, participants were asked to rate each concern on a 10 -point scale, where 1 = "little to no importance," 5 = "somewhat important," and $10=$ "upmost importance."

\subsection{Monitoring polar bear health: current efforts, knowledge gaps and potential challenges}

In the first round, participants were asked if adequate effort is currently being devoted in monitoring polar bear health. Responses were summarized as percentages for "yes," "no," and "not sure/did not clarify" categories. Although not explicitly requested in the first-round questionnaire, all participants provided comments or justification to substantiate their responses. These qualitative responses were summarized into 16 themes regarding the obstacles and important knowledge gaps in monitoring health in polar bears. In the second round, participants were asked to indicate their agreement with a check-allthat-apply for each of the 16 categories that represent the overarching requirements needed to adequately assess and monitor polar bear health.

\subsection{Important metrics and critical indicators to monitor polar bear health}

Concurrent to defining polar bear health, participants were asked in the first round to identify the most important metrics or critical indicators to monitor health in polar bears. A condensed list was then developed of 15 important metrics and indicators. In the second round participants were asked to rate the level of importance of each metric/ indicator on a scale of 1 ("little to no importance") to 10 ("extremely important").

\section{Results}

Fifteen experts were invited to participate in the Delphi exercise. Of these, 14 agreed to participate, and 13 of the 14 experts completed both the first- and second-round questionnaires. Experts represented four countries, had expertise on eight polar bear subpopulations, and included affiliates of government agencies, research or academic institutions, and nonprofit organizations with backgrounds in biology, ecology, and veterinary medicine.

\subsection{Defining polar bear health}

In the first round, the mean level of agreement among experts on the application of the definition of wildlife health reported by Hanisch et al. (2012) to polar bear health was 8.08 on a scale of 1 to 10 with 10 representing strong agreement (median $=8.5$, mode $=10$, range $=$ 4-10). The proposed changes to the definition made by experts in the first round were summarized into 17 statements for rating in the second round. The proposed changes related to several broad categories: (1) the scale of the definition from individual to populations to the ecosystem level and whether or not the definition should focus on an individual or on a population, (2) terminology, for example use of "stressors" versus "factors," and (3) the level of specificity of the definition in describing physiologic effects versus a broader description of the cumulative effects on the health status of polar bears (Supplementary material Table S1).

Most participants agreed that the scope of the definition should include the concepts of populations and ecosystems (e.g., 10/13 said that deleting "populations and ecosystems" would decrease their level of agreement) and disagreed with proposed changes to focus on individuals versus the population (8/13). Of the participants, $62 \%$ thought that changing "stressors" to "factors" would improve the definition (decrease: 0\%, neither: 38\%). Most participants preferred to keep the words "sustain itself" in the definition (69\% indicated that removing the words would decrease their agreement), and expand upon that statement to say "long term" (improve or neither: 77\%). Generally, proposed changes supported including holistic effects on polar bears (e.g., including environmental factors in the definition).

Based upon the second-round ratings and written comments in the first and second rounds, a revised definition of polar bear health resulted from the Delphi exercise: "Polar bear health is a multidisciplinary concept and is concerned with multiple factors that affect polar bears. Polar bear health can be applied at the individual, species, and ecosystem levels, but its most important defining characteristics are whether a population can respond to factors in its environment and sustain itself long term."

\subsection{Identifying the most significant concerns to polar bear health over the next 20 years}

Eight major themes in three broad categories (biological, social, and ecological) emerged from the first-round questionnaire, where respondents identified the most significant concerns to polar bear health over the next 20 years (Table 1 ). Among the concerns identified, environmental change and related effects were mentioned by all 13 respondents. In the second round, respondents were asked to rate each of 
Table 1

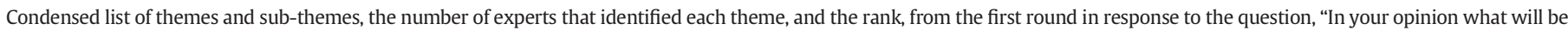
the most significant concerns to polar bear health over the next 20 years?" The number of experts that identified each theme is provided in parentheses ( $\mathrm{n}=13$ ).

\begin{tabular}{|c|c|c|c|}
\hline Theme & Sub-theme & $\begin{array}{l}\text { No. of experts identifying } \\
\text { the theme }(n)\end{array}$ & Rank \\
\hline Climate change & $\begin{array}{l}\text { - Loss of sea ice } \\
\text { - Habitat loss } \\
\text { - Decreased access and availability of prey } \\
\text { - Increased energy costs/constraints associated with increased movement in search of prey }\end{array}$ & 13 & 1 \\
\hline Diseases and parasites & $\begin{array}{l}\text { - Emerging diseases } \\
\text { - Exposure to pathogens } \\
\text { - Susceptibility } \\
\text { - Diversity of pathogens }\end{array}$ & 8 & 2 \\
\hline Increased exposure to contaminants & & 7 & 3 \\
\hline Increased nutritional stress & & 5 & 4 \\
\hline Increased frequency of human interactions & $\begin{array}{l}\text { - Due to industrialization } \\
\text { - Due to tourism } \\
\text { - Human-bear conflict }\end{array}$ & 5 & 4 \\
\hline Harvest management & & 3 & 5 \\
\hline Chronic physiologic stress & & 2 & 6 \\
\hline Increased exposure to competitors & - Brown bears (Ursus arctos) & 1 & 7 \\
\hline
\end{tabular}

the eight themes on a scale of 1 (little to no importance) to 10 (upmost importance). "Climate change" was identified as the most important concern, with a mean score of 9.58 (median $=10$ ) (Fig. 1, Supplementary material Table S2). "Increased nutritional stress" ( mean $=8.58$ ) and "chronic physiologic stress" (mean $=6.55$ ) received the next highest mean scores. "Increased exposure to competitors" received the lowest mean importance ( mean $=2.00$ ) with 11 of 12 respondents giving the theme the lowest (or tied for lowest) importance of the eight themes scored.

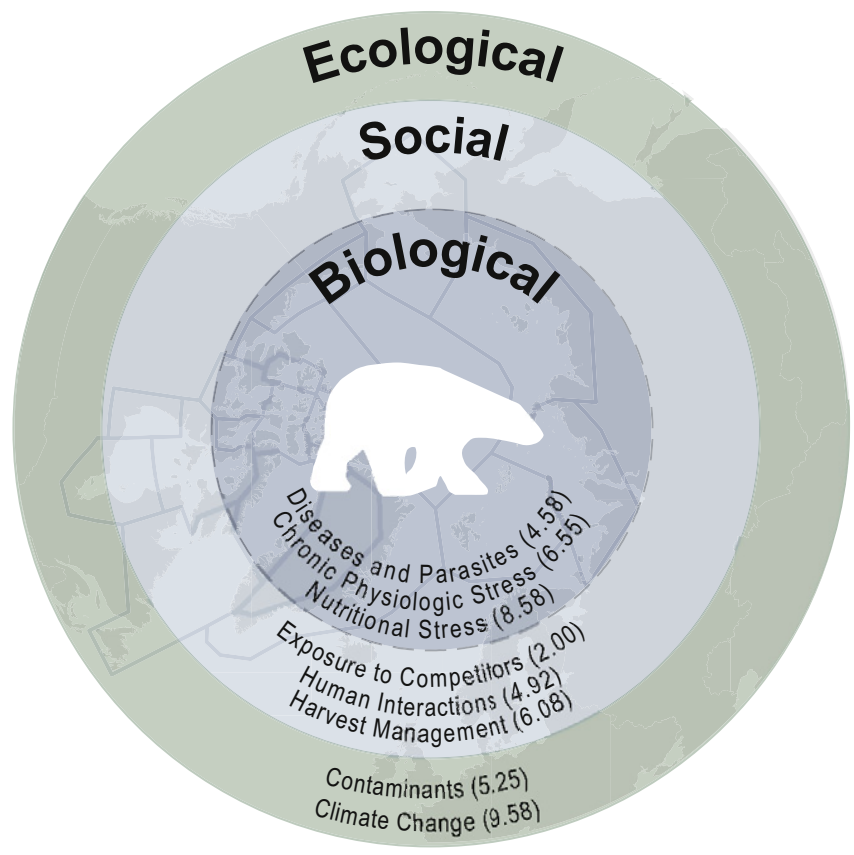

Fig. 1. Important concerns to polar bear health, grouped into 3 categories-biological, social, and ecological-depicted by the concentric circles. The 8 central themes listed within the figure are topics which emerged from first-round questionnaire responses about concerns to polar bear health over the next 20 years. The means of the second-round questionnaire scores are given in parentheses where respondents rated each concern on a scale from 1 to 10 where $1=$ "the concern is of little to no importance to polar bear health over the next 20 years" and $10=$ "the concern is of utmost importance to polar bear health over the next 20 years." The background represents the circumpolar distribution of polar bear subpopulations. The figure intends to illustrate the complexity and interrelatedness of the concerns to polar bear health across multiple levels and to emphasize the importance of integrated monitoring of health determinants across subpopulations.

\subsection{Monitoring polar bear health: current efforts, knowledge gaps and} potential challenges

In the first round, participants were asked to indicate if adequate effort is currently being devoted to monitoring polar bear health. Over half of the respondents (62\%) said that adequate effort is not being devoted to polar bear health. Only one participant $(8 \%)$ responded that adequate effort is being devoted to monitoring polar bear health but with caveats, and approximately one-third of respondents (31\%) indicated that they were either not sure or they provided comments but not a definitive yes/no response. Several respondents answered that globally adequate effort is not being devoted to monitoring polar bear health, but that in some cases local sample collection for certain aspects of health (e.g., contaminants) is taking place.

Comments and justifications provided to corroborate responses in the first round were summarized into 16 needs and statements (Table 2). In the second round, participants were asked to indicate whether or not they agreed with each of the 16 themes. All 13 respondents agreed that the following needs exist: (1) systematic and standardized monitoring and data collection to allow for comparisons across populations, (2) examination of the effects of health factors (not just characterization), and (3) cooperation, collaboration, and communication across regions (i.e., a circumpolar effort) (Table 2). Of the 16 first-round summary statements, the need to investigate safety for human consumption, received the lowest percentage agreement (15\%).

\subsection{Important metrics and critical indicators to monitor polar bear health}

Fifteen important metrics or critical indicators to monitor polar bear health were summarized from participants' qualitative responses to the first-round questionnaire (Table 3). The indicators/metrics most frequently identified included "body condition metrics" (10 of 13 respondents), "diseases and parasites," and "contaminant load or exposure" (each identified by 8 of 13 respondents). In the second round, participants were asked to indicate on a scale of 1 (little to no importance) to 10 (extremely important) the level of importance of each of the metrics/indicators to monitor health in polar bears. The highest mean levels of agreement included "body condition metrics" ( $m e a n=9.82$ ), "measures of reproductive success" (mean $=8.91$ ), "survival" (mean $=8.82$ ), and "morphometric measurements" ( mean $=8.60)$. "Nutritional deficiencies" ( mean $=3.30$ ) had the lowest mean level of agreement (Table 4). 
Table 2

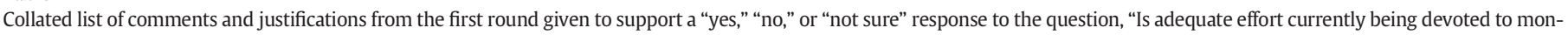

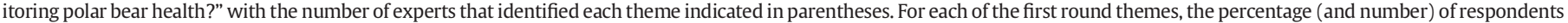
who in the second round agreed that the topic represents the overarching need to adequately assess and monitor polar bear health.

Knowledge gaps and needs to adequately assess and monitor polar bear health (number of respondents)

Percent agreement

(number of respondents)

A need exists for systematic and standardized monitoring and data collection to allow for comparisons across populations. (6)

A need exists to examine the effects of health factors (e.g., climate change, contaminants, diseases) not just characterize them. (4)

$100 \%(13)$

$100 \%(13)$

A need exists for cooperation, collaboration, and communication across regions (i.e, a circumpolar effort) in order to monitor polar bear health. (4) $100 \%$ (13)

A need exists to integrate information and expertise from various disciplines in order to adequately study polar bear health (e.g., climate, disease, $92 \%$ (12)

ecology, contaminants). (2)

A need exists for comprehensive health assessments (i.e., collect samples and interpret results concurrently from a suite of tests and measurements). (2)

Funding and support is needed to focus on health-related questions. (1)

A need exists for long-term health monitoring projects. (2)

Individual polar bear capture should be supported for adequate data collection. (1)

A need exists to study susceptibility to disease. (2)

An overall need exists to focus research efforts on polar bear health. (1)

A need exists to monitor ecosystem health. (1)

A need exists to study the adequacy of the food supply. (1)

A need exists to study population sustainability. (1)

A need exists to investigate the effects of hunting. (1)

Intentional avoidance of adequate health monitoring in polar bears may be taking place. (1)

A need exists to investigate hunter harvest safety

(i.e., safety for human consumption). (1)
$85 \%(11)$

$85 \%(11)$

$77 \%(10)$

$69 \%$ (9)

$69 \%(9)$

$54 \%(7)$

$54 \%(7)$

$38 \%(5)$

$38 \%$ (5)

$31 \%$ (4)

$23 \%(3)$

$15 \%(2)$

\section{Discussion}

Wildlife health research, to date, has mostly been reactive and disease-centric, with an emphasis on responding to existing or imminent animal health events (Stephen, 2014). The idea of health as the absence of disease is antiquated. The concept of health in the human medical field has long since moved past the disease-centric definition and has adopted a view of health as a cumulative effect that is a

Table 3

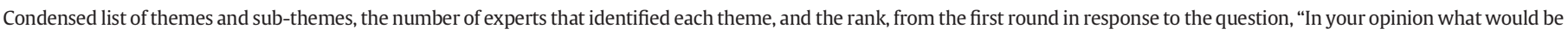
important metrics or critical indicators to monitor health in polar bears? " $(n=13)$.

\begin{tabular}{|c|c|c|c|}
\hline Theme & Sub-theme & No. of experts identifying the theme (n) & Rank \\
\hline Body condition metrics & $\begin{array}{l}\text { - Visual observation } \\
\text { - Condition index } \\
\text { - Mass } \\
\text { - Fat thickness } \\
\text { - Fat cell lipid content } \\
\text { - Bioelectrical impedance } \\
\text { - Energy density }\end{array}$ & 10 & 1 \\
\hline Diseases and parasites & & 8 & 2 \\
\hline Contaminant load or exposure & $\begin{array}{l}\text { - Organic pollutants } \\
\text { - Heavy metals } \\
\text { - Tissue samples }\end{array}$ & 8 & 2 \\
\hline Measures of reproductive success & $\begin{array}{l}\text { - Litter production rates } \\
\text { - Litter size } \\
\text { - Age-specific } \\
\text { - Denning distribution and success } \\
\text { - Presence and frequency of reproductive malformations }\end{array}$ & 6 & 3 \\
\hline Survival & $\begin{array}{l}\text { - Age-specific } \\
\text { - Sex-specific }\end{array}$ & 5 & 4 \\
\hline Stress response & $\begin{array}{l}\text { - Hair cortisol levels } \\
\text { - Tissue samples } \\
\text { - Heat shock proteins }\end{array}$ & 5 & 4 \\
\hline Population trends & $\begin{array}{l}\text { - Size and composition } \\
\text { - Sex, age, reproductive status }\end{array}$ & 4 & 5 \\
\hline Morphometric measurements & $\begin{array}{l}\text { - Zygomatic width } \\
\text { - Skull length }\end{array}$ & 4 & 5 \\
\hline Ecologic metrics & $\begin{array}{l}\text { - Sea ice monitoring } \\
\text { - Timing of sea ice break-up } \\
\text { - Amount of summer sea ice } \\
\text { - Bioclimate metrics }\end{array}$ & 3 & 6 \\
\hline Integrative monitoring programs that include: & $\begin{array}{l}\text { - Environmental factors } \\
\text { - Climate, disease } \\
\text { - Health } \\
\text { - Reproductive success } \\
\text { - Survival }\end{array}$ & 2 & 7 \\
\hline Immune function & & 2 & 7 \\
\hline Necropsy/pathology & & 2 & 7 \\
\hline Tissue measurements for health & - Health of individual bears and health as a human subsistence resource & 2 & 7 \\
\hline Nutritional deficiencies & $\begin{array}{l}\text { - Vitamins } \\
\text { - Trace minerals }\end{array}$ & 1 & 8 \\
\hline Distribution and habitat use & & 1 & 9 \\
\hline
\end{tabular}




\section{Table 4}

Condensed list of important metrics and indicators to monitor polar bear health enumerated in the first round questionnaire, and the mean, median, and range of the second round scores rating each metric/indicator on a scale of 1 to 10 where $1=$ "the metric is of little to no importance to monitor polar bear health" and $10=$ "the metric is of utmost importance to monitor health in polar bears."

\begin{tabular}{llll}
$\begin{array}{l}\text { Important metrics and critical indicators to } \\
\text { monitor health in polar bears }\end{array}$ & $\begin{array}{l}\text { Level of agreement on a 10-point } \\
\text { scale with 10 indicating utmost } \\
\text { importance }\end{array}$ \\
\cline { 2 - 4 } & Mean & Median & Range \\
\hline Body condition metrics & 9.82 & 10.00 & $8-10$ \\
Measures of reproductive success & 8.91 & 10.00 & $5-10$ \\
Survival & 8.82 & 10.00 & $5-10$ \\
Morphometric measurements & 8.60 & 10.00 & $3-10$ \\
Population trends & 8.09 & 10.00 & $5-10$ \\
Ecologic metrics & 7.64 & 8.00 & $1-10$ \\
Integrative monitoring programs ${ }^{1}$ & 7.20 & 7.50 & $1-10$ \\
Stress response & 6.55 & 5.00 & $4-10$ \\
Disease and parasite exposure or status & 6.45 & 7.00 & $3-10$ \\
Necropsy/pathology & 6.30 & 6.00 & $3-10$ \\
Contaminant load or exposure & 6.09 & 6.00 & $3-9$ \\
Distribution and habitat use & 5.60 & 4.00 & $1-10$ \\
Immune function & 5.45 & 5.00 & $2-9$ \\
Tissue measurements for health & 4.10 & 5.00 & $1-9$ \\
Nutritional deficiencies & 3.30 & 3.00 & $1-5$ \\
\hline
\end{tabular}

1 E.g., A program that studies the effects of multiple stressors by integrating research groups from different disciplines.

product of biological, social, and environmental factors. Wildlife health is just beginning to be re-framed from the view of health as absence of disease to being characterized in the context of vulnerability and resilience (Hanisch et al., 2012; Stephen, 2014).

One objective of this exercise was to propose a working definition of polar bear health to support the development of measureable standards of health and the establishment of meaningful programs to monitor polar bear health. In general, there was good agreement among the experts regarding the definition that was established through the Delphi exercise. One area of debate was concerned with the scope of the definition-for example, if it should focus on the individual, population, or ecosystem. Ultimately, the resulting definition articulated that "polar bear health can be applied at the individual, population, and ecosystem levels." The level to which health should be applied is a relatively new concept for animal health but it is one that is being more frequently discussed. For example, a recent Delphi exercise to define "wildlife health" considered populations to be the most important scale, although it was reported that participants in that exercise debated on the focus of the definition of "wildlife health" (Hanisch et al., 2012). Similarly, Stephen (2014) describes wildlife health as the result of interacting biological, social, and environmental factors. The definition of polar bear health is explicitly holistic in that it recognizes the importance of viewing health as a product of behavioral and physiological responses to changing environmental conditions and the many interacting factors that could affect the vulnerability and sustainability of the species.

Climate change was most frequently identified as a concern to polar bear health over the next 20 years. Climate change and other ecological factors (increased nutritional stress and chronic physiologic stress) ranked as the top three concerns to polar bear health. The five most important indicators to monitor polar bear health included direct measurements of health obtained through population dynamics studies (e.g., metrics of survival and reproduction), with "ecological metrics" ranking sixth on the list. It is important to consider the results of the Delphi in aggregate. For example, do the identified indicators adequately measure the effects of the top concern, climate change, on polar bear health? A substantial amount of the current polar bear research is related to population ecology studies (e.g., Vongraven et al., 2012), and the generated list of indicators important for health closely aligns with data collected for those studies. It is possible that these data best reflect polar bear health, but it is also important to consider that the results of a Delphi exercise inherently reflect the specialties represented on the panel (Goluchowicz and Blind, 2011; Hus and Sandford, 2007). In this study, the expert group included polar bear biologists studying primarily at the population-level. Some experts commented that certain aspects of health and assessment methodologies are outside their area of expertise. Others said that in some cases technology to monitor health in polar bears is unavailable, and in other cases the data and tools might be available to measure health but the capability and knowledge to integrate them may not be. Input from other groups and disciplines, for example subsistence users, Arctic village citizens, physiologists, veterinarians, or climate scientists, may have introduced alternative viewpoints, changing the indicators and their rankings. Additionally, responses may have varied if the indicators were identified after establishing the working definition of polar bear health rather than concurrently. This exercise underscored the challenges in characterizing the complex relationships between potential health indicators and health outcomes. The proposed list could be used as a basis to further explore these topics.

The Delphi approach is a commonly used group process method with several recent applications in the field of animal health (e.g., Hanisch et al., 2012; Wendholt et al., 2012). Expert participation in both surveys was high. The use of the Delphi process likely removed potential obstacles to participation such as language barriers and time zone differences, improving response rates and reducing regional bias. Collaborative approaches which minimize obstacles to participation, such as the Delphi, can be helpful to effectively address multidimensional issues, such as wildlife health. However, group elicitation techniques may identify as many new questions as they resolve. This result can be seen as a benefit for developing fields exploring new directions or trends. Conversely, a limitation of remote panel processes such as the Delphi is the restricted opportunity to discuss emerging themes. Expanding on these new questions may require follow-up panels, literature reviews, or new research efforts.

One example of an emerging theme was that a need exists to move beyond characterizing health factors and to improve our understanding of the effects on population vital rates, including the interactive effects between factors such as climate change and contaminants and disease exposure. Likewise, a need exists to integrate information and expertise from various disciplines in order to adequately study polar bear health-for example, linking the monitoring of health and environmental metrics, and relating that interaction back to population dynamics. These themes have recently been explored conceptually (e.g., Acevedo-Whitehouse and Duffus, 2009; Sonne, 2010); however, putting these concepts into practice is challenging as the links between polar bear data and information from other disciplines are not clear. Considering these complexities and the methodological approaches to address them was beyond the scope and aims of the exercise, but this emerging topic is a critical one that could be developed though group decision making processes or other studies.

\subsection{Considerations}

The linkages between rapid environmental change and negative consequences for polar bears have sparked concern about the effects that such changes may have on the health of this ice-adapted Arctic species. Understanding the response of polar bear subpopulations to these changes may be important in meeting the conservation needs of this species, particularly if changes act synergistically with habitat loss to adversely influence population dynamics. However, it is currently unknown whether or not and to what extent environmental changes will affect polar bear health and subsequently conservation. Rather than being reactive to an urgent conservation need, this exercise was intended to serve as a starting point from which to conceptualize polar bear health and how it might be measured within the context of environmental change. 
Polar bears are a sentinel species in the Arctic ecosystem through which the cumulative effects of current and future stressors may be studied (Stirling and Derocher, 1993; Vongraven et al., 2012). Cumulative effects studies explore the impact of independent and interacting risk factors from multiple sources (Moore and Huntington, 2008; Ragan et al., 2008). These changes can be a result of natural or anthropogenic pressures that are individually minor but could collectively be significant over time. The working definition of polar bear health could represent the first step towards characterizing a cumulative effects framework to study the vulnerability and resistance of the species. We propose as a next step towards a cumulative effects framework, that the information collected in the Delphi exercise be further explored to identify several key variables that reflect the working definition of polar bear health. This could be accomplished in part through decision-science methods involving experts from a broad range of disciplines. These variables might then form the basis to create a validated framework for measuring and assessing polar bear health that considers the biological, ecological, and social determinants of health and promotes collaboration in health monitoring across subpopulations.

\section{Conclusions}

The Delphi exercise highlighted a need for an integrated, circumpolar, approach to better understand the response of polar bear subpopulations to the accumulating challenges of natural and anthropogenic change. Examining data in isolation fails to monitor the cumulative impact that these changes may have on polar bear health and conservation. Developing a holistic understanding of the responses of polar bear subpopulations to these challenges is vital in order to meet the growing conservation needs of the species.

\section{Acknowledgments}

The authors wish to thank Karyn Rode, Lily Peacock, Andrew Derocher, Ian Stirling, Steven Amstrup, and George Durner, who also served on the expert panel and provided valuable insight through their thoughtful participation in the survey. We also thank Philip Riggs for his assistance with the manuscript images. Any use of trade, firm, or product names is for descriptive purposes only and does not reflect endorsement by the federal government.

\section{Appendix A. Supplementary data}

Supplementary data to this article can be found online at http://dx. doi.org/10.1016/j.scitotenv.2015.02.007.

\section{References}

Aars, J., Lunn, N.J., Derocher, A.E. (Eds.), 2006. Polar Bears. Proceedings of the 14th Working Meeting of the IUCN/SSC Polar Bear Specialist Group, 2005 June 20-24; Seattle Washington, USA. Occasional Paper of the IUCN Species Survival Commission, No. 32, International Union for the Conservation of Nature, Gland, Switzerland and Cambridge, United Kingdom.

Acevedo-Whitehouse, K., Duffus, A.L.J., 2009. Effects of environmental change on wildlife health. Philos. Trans. R. Soc. Lond. B Biol. Sci. 364, 3429-3438.

Aguirre, A.A., Tabor, G.M., 2004. Introduction: marine vertebrates as sentinels of marine ecosystem health. EcoHealth 1, 236-238.

AMAP, 1998. AMAP Assessment Report: Arctic Pollution Issues. Arctic Monitoring and Assessment Programme (AMAP), Oslo, Norway.

AMAP, 2003. AMAP Assessment 2002: Human Health in the Arctic. Arctic Monitoring and Assessment Programme (AMAP), Oslo, Norway.

AMAP, 2004. AMAP Assessment 2002: Persistent Organic Pollutants in the Arctic. Arctic Monitoring and Assessment Programme (AMAP), Oslo, Norway.

Bentzen, T.W., Follmann, E.H., Amstrup, S.C., York, G.S., Wooller, M.J., O'Hara, T.M., 2007. Variation in winter diet of southern Beaufort Sea polar bears inferred from stable isotope analysis. Can. J. Zool. 85, 596-608.

Boonstra, R., McColl, C.J., Karels, T.J., 2001. Reproduction at all costs: the adaptive stress response of male Arctic ground squirrels. Ecology 82, 1930-1946.

Bossart, G.D., 2011. Marine mammals as sentinel species for oceans and human health. Vet. Pathol. 48, 676-690.
Dalkey, N., Helmer, O., 1962. An experimental application of the Delphi method to the use of experts. Manag. Sci. 9, 458-467.

Deem, S.L., Parker, P.G., Miller, R.E., 2008. Building bridges: connecting the health and conservation professions. Biotropica 40, 662-665.

Derocher, A.E., 2010. Climate change: the prospects for polar bears. Nature 468, 905-906.

Durner, G.M., Douglas, D.C., Nielson, R.M., Amstrup, S.C., McDonald, T.L., Stirling, I., et al., 2009. Predicting 21st-century polar bear habitat distribution from global climate models. Ecol. Monogr. 79, 25-58.

Fischbach, A.S., Amstrup, S.C., Douglas, D.C., 2007. Landward and eastward shift of Alaskan polar bear denning associated with recent sea ice changes. Polar Biol. 30, 1395-1405.

Goluchowicz, K. Blind, K, 2011. Identification of future fields of standardisation: an explorative application of the Delphi methodology. Technol. Forecast. Soc. 78, 1526-1541.

Gunnarsson, S., 2006. The conceptualization of health and disease in veterinary medicine. Acta Vet. Scand. 48, 20.

Hanisch, S.L., Riley, S.J., Nelson, M.P., 2012. Promoting wildlife health or fighting wildlife disease: insights from history, philosophy, and science. Wildl. Soc. Bull. 36, 477-482.

Herreman, J., Peacock, E., 2013. Polar bear use of a persistent food subsidy: insights from non-invasive genetic sampling in Alaska. Ursus 24, 148-163.

Hobson, K.A., Welch, H.E., 1992. Determination of trophic relationships within a high Arctic marine food web using $\delta^{13} \mathrm{C}$ and $\delta^{15} \mathrm{~N}$ analysis. Mar. Ecol. Prog. Ser. 9-18.

Hueffer, K., O'Hara, T.M., Follmann, E.H., 2011. Adaptation of mammalian host-pathogen interactions in a changing Arctic environment. Acta Vet. Scand. 53, 17.

Hueffer, K., Parkinson, A.J., Gerlach, R., Berner, J., 2013. Zoonotic infections in Alaska: disease prevalence, potential impact of climate change and recommended actions for earlier disease detection, research, prevention and control. Int. J. Circumpolar Health $72,19562$.

Hus, C.-C., Sandford, B.A., 2007. The Delphi technique: making sense of consensus. Pract. Assess. Res. Eval. 12, 1-8.

Laidre, K.L., Stirling, I., Lowry, L.F., Wigg, Ø., Heide-Jørgensen, M.P., Ferguson, S.H., 2008. Quantifying the sensitivity of Arctic marine mammals to climate-induced habitat change. Ecol. Appl. 18, S97-S125.

Letcher, R.J., Bustnes, J.O., Dietz, R., Jenssen, B.M., Jørgensen, E.H., Sonne, C., et al., 2010. Exposure and effects assessment of persistent organohalogen contaminants in Arctic wildlife and fish. Sci. Total Environ. 408, 2995-3043.

Lunn, N. Schliebe, S. Born, EW. (Eds.), 2002. Polar Bears. Proceedings of the 13th Working Meeting of the IUCN/SSC Polar Bear Specialist Group, 2001 23-28 June; Nuuk, Greenland. Occasional Paper of the IUCN Species Survival Commission, No. 26, International Union for the Conservation of Nature, Gland, Switzerland and Cambridge, United Kingdom

Molnár, P.K., Derocher, A.E., Klanjscek, T., Lewis, M.A., 2011. Predicting climate change impacts on polar bear litter size. Nat. Commun. 2, 186

Moore, S.E., 2008. Marine mammals as ecosystem sentinels. J. Mammal. 89, 534-540.

Moore, S.E., Huntington, H.P., 2008. Arctic marine mammals and climate change: impacts and resilience. Ecol. Appl. 18, S157-S165.

Nordenfelt, L., 2011. Health and welfare in animals and humans. Acta Biotheor. 59, 139-152.

Obbard, M.E., Thiemann, G.W., Peacock, E., DeBruyn, T.D. (Eds.), 2010. Polar Bears. Proceedings of the 15th Working Meeting of the ICUN/SSC Polar Bear Specialist Group, 200929 June-3 July; Copenhagen, Denmark. Occasional Paper of the IUCN Species Survival Commisssion, No. 43, International Union for the Conservation of Nature, Gland, Switzerland and Cambridge, United Kingdom.

Ragan, T.J., Huntington, H.P., Hovelsrud, G.K., 2008. Conservation of Arctic marine mammals faced with climate change. Ecol. Appl. 18, S166-S174.

Reeves, R.R., Ewins, P.J., Agbayani, S., Heide-Jørgensen, M.P., Kovacs, K.M., Lydersen, C., et al., 2014. Distribution of endemic cetaceans in relation to hydrocarbon development and commercial shipping in a warming Arctic. Mar. Policy 44, 375-389.

Regehr, E.V., Lunn, N.J., Amstrup, S.C., Stirling, I., 2007. Effects of earlier sea ice breakup on survival and population size of polar bears in western Hudson Bay. J. Wildl. Manag. 71, 2673-2683.

Regehr, E.V., Hunter, C.M., Caswell, H., Amstrup, S.C., Stirling, I., 2010. Survival and breeding of polar bears in the southern Beaufort Sea in relation to sea ice. J. Anim. Ecol. 79, 117-127.

Rode, K.D., Amstrup, S.C., Regehr, E.V., 2010. Reduced body size and cub recruitment in polar bears associated with sea ice decline. Ecol. Appl. 20, 768-782.

Rode, K.D., Regehr, E.V., Douglas, D.C., Durner, G., Derocher, A.E., Thiemann, G.W., et al., 2014. Variation in response of an Arctic top predator experiencing habitat loss: feeding and reproductive ecology of two polar bear populations. Glob. Chang. Biol. 20, $76-88$.

Rowe, G., Wright, G., 1999. The Delphi technique as a forecasting tool: issues and analysis. Int. J. Forecast. 15, 353-375.

Schliebe, S., Rode, K.D., Gleason, J.S., Wilder, J., Proffitt, K., Evans, T.J., et al., 2008. Effects of sea ice extent and food availability on spatial and temporal distribution of polar bears during the fall open-water period in the southern Beaufort Sea. Polar Biol. 31, 999-1010.

Sonne, C., 2010. Health effects from long-range transported contaminants in Arctic top predators: an integrated review based on studies of polar bears and relevant model species. Environ. Int. 36, 461-491.

Sonne, C., Letcher, R.J., Bechshøft, T.Ø., Rigét, F.F., Muir, D.C.G., Leifsson, P.S., et al, 2012. Two decades of biomonitoring polar bear health in Greenland: a review. Acta Vet. Scand. 54, S15.

Stephen, C., 2014. Toward a modernized definition of wildlife health. J. Wildl. Dis. 50, 427-430.

Stephen, C., Karesh, W.B., 2014. Is 'One Health' delivering results? Rev. Sci. Tech. Off. Int. Epiz. 33, 375-379.

Stirling, I., Derocher, A.E., 1993. Possible impacts of climate warming on polar bears. Arctic $46,240-245$. 
Stirling, I., Derocher, A.E., 2012. Effects of climate warming on polar bears: a review of the evidence. Glob. Chang. Biol. 18, 2694-2706.

Stirling, I., Parkinson, C.L., 2006. Possible effects of climate warming on select populations of polar bears (Ursus maritimus) in the Canadian Arctic. Arctic 59, 261-275.

Towns, L., Derocher, A.E., Stirling, I., Lunn, N.J., Hedman, D., 2009. Spatial and temporal patterns of problem bears in Churchill, Manitoba. Polar Biol. 332, 1529-1537.

Towns, L., Derocher, A.E., Stirling, I., Lunn, N.J., 2010. Changes in land distribution of polar bears in western Hudson Bay. Arctic 73, 28212-28303.

Vongraven, D., Aars, J., Amstrup, S., Atkinson, S.N., Belikov, S., Born, E.W., et al., 2012. A circumpolar monitoring framework for polar bears. Ursus 23, 1-66.
Wayland, M., Gilchrist, H.G., Marchant, T., Keating, J., Smits, J.E., 2002. Immune function, stress response, and body condition in Arctic-breeding common eiders in relation to cadmium, mercury, and selenium concentrations. Environ. Res. 90, 47-60.

Wendholt, M.T.A., Cardoen, S., Imberechts, H., Van Huffel, X., Ooms, B.W., Frewer, L.J.

2012. Defining European preparedness and research needs regarding emerging infectious animal diseases: results from a Delphi expert consultation. Prev. Vet. Med. 103, 81-92.

Wiig, Ø., 2005. Are polar bears threatened? Science 309, 1814-1815. 